\title{
PANDUAN PRAKTIS IMPLEMENTASI MODEL PEMBELAJARAN EXO OLO TASK \\ PADA PEMBELAJARAN GEOGRAFI
}

Secara umum profil Model Pembelajaran EXO OLO TASK dapat dicermati melalui gambar berikut ini;

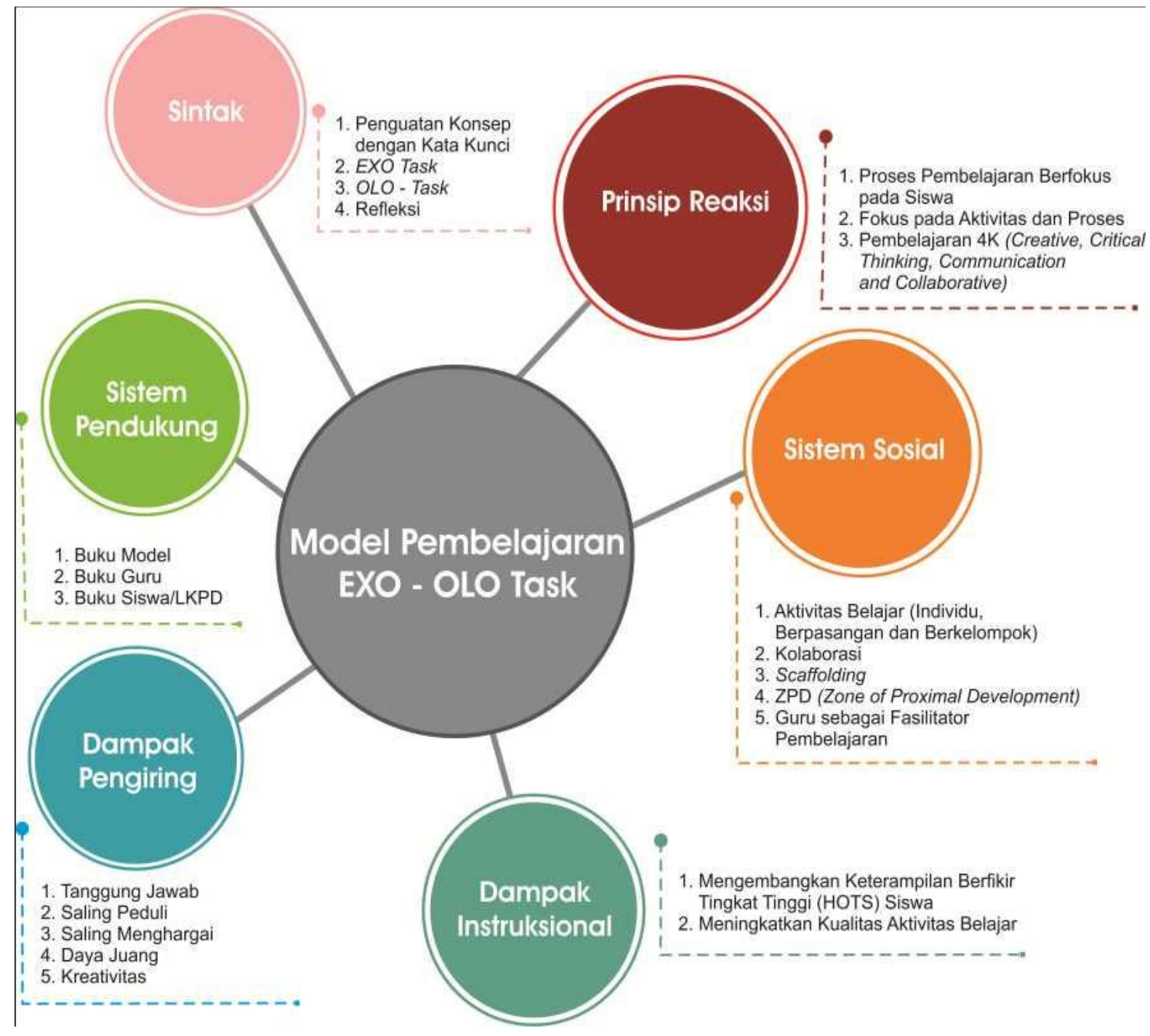

Gambar 1. Model Pembelajaran EXO OLO Task

\section{A. Pengertian}

Model Pembelajaran EXO - OLO TASK adalah pengembangan dari model pembelajaran kolaboratif pada pembelajaran Geografi yang bertujuan untuk 
mengembangkan keterampilan berpikir tinggi siswa melalui penataan aktivitas belajar dan kolaborasi yang dipicu oleh dua jenis soal yaitu EXO TASK dan OLO TASK. Model pembelajaran ini terdiri dari empat sintaks yaitu, 1) penguatan konsep (Strengthening Concept), 2) paket soal C1 - C3 atau (EXO TASK), 3) paket soal C4 - C6 atau OLO TASK dan 4) refleksi proses pembelajaran.

\section{B. Tujuan}

Tujuan Model Pembelajaran EXO OLO TASK ini adalah:

1. Mengembangkan aktivitas belajar siswa dalam pembelajaran baik aktivitas belajar dasar (basic learning activity) maupun aktivitas belajar lanjut (advance learning activity).

2. Memfasilitas siswa untuk belajar secara individu, berpasangan dan berkelompok dalam rangka mengembangkan nilai-nilai dan sikap sosial diantara mereka.

3. Memberi ruang kepada siswa untuk berinteraksi dan berkolaborasi untuk mencapai keberhasilan dalam pembelajaran secara bersama dan berkelanjutan.

4. Melatih kemampuan guru dalam merancang soal LOTS, MOTS dan HOTS.

5. Mengembangkan keterampilan berpikir tingkat tinggi siswa.

\section{Manfaat}

Manfaat yang diharapkan dari adanya model pembelajaran EXO OLO TASK ini adalah:

1. Berkembangnya keterampilan berpikir tingkat tinggi siswa.

2. Meningkatnya kualitas aktivitas belajar siswa.

3. Bagi Guru, diharapkan dapat meningkatkan dan mengasah kompetensi pedagogik dan profesional guru terutama terkait dengan kemampuan dalam hal merancang tugas atau soal serta instrument/alat ukur hasil belajar secara berkesinambungan. Manfaat lain adalah mendorong guru 
untuk mengembangkan kolaborasi dalam menjalani profesi sebagai pendidik mulai dari tahap perencanaan, pelaksanaan sampai penilaian pembelajaran.

4. Bagi keilmuan, diharapkan model pembelajaran ini menambah daftar model-model pembelajaran yang bisa dipilih guru dalam meningkatkan kualitas pembelajaran, khususnya pada mata pelajaran Geografi.

5. Bagi praktisi dan peneliti, diharapkan model ini menjadi kajian lanjutan dan mendorong untuk melakukan penelitian sebagai kelanjutan dari ide-ide yang telah dikembangkan sebelumnya.

\section{Komponen Inti Operasional Model Pembelajaran}

\section{Sintaks Pembelajaran.}

Secara sederhana alur pelaksanaan tahapan pembelajaran menggunakan Model Pembelajaran EXO OLO TASK terlihat pada gambar berikut ini;

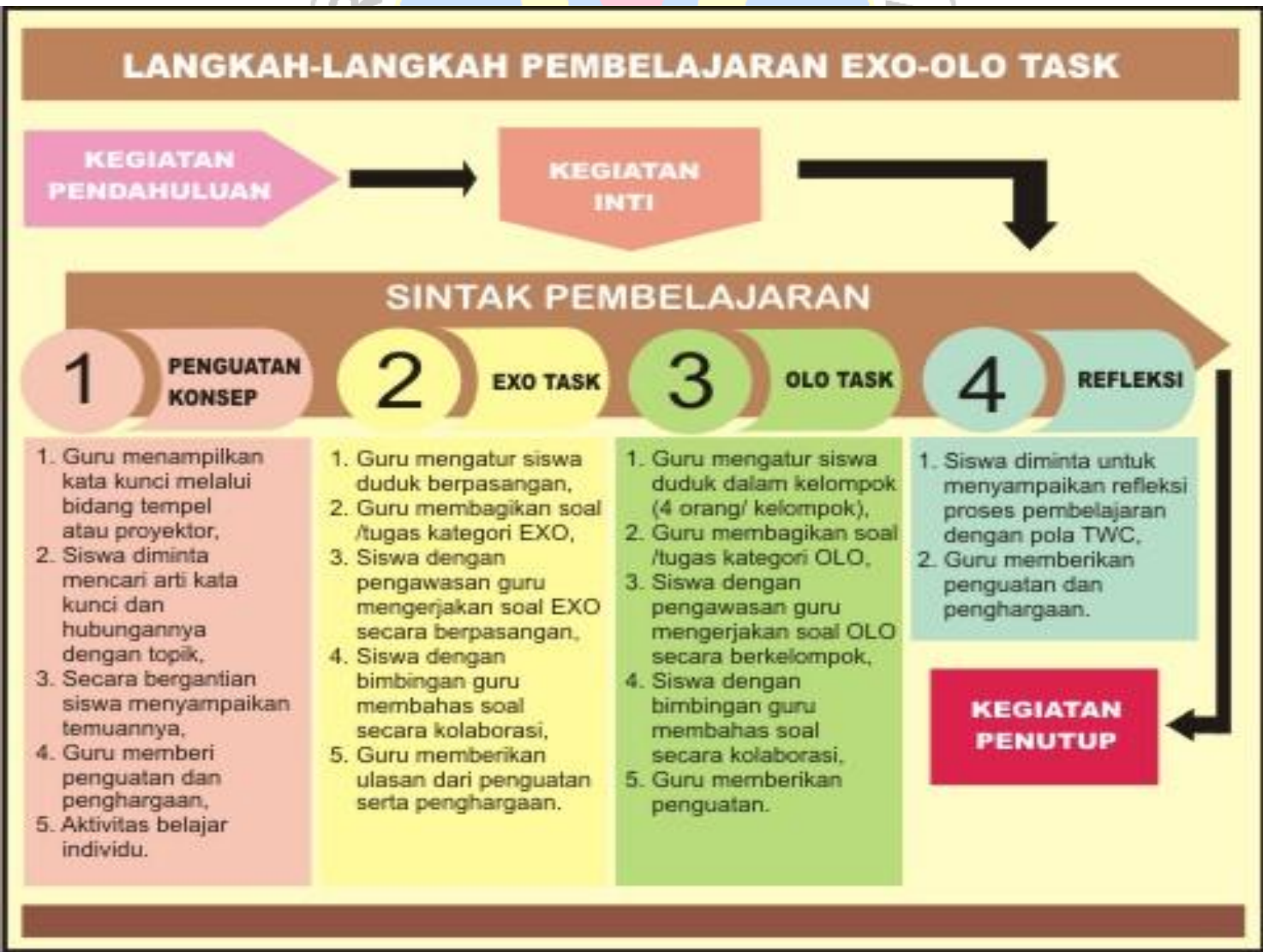

Gambar 2. Gambaran Sintak Model Pembelajaran EXO OLO Task 
Landasan teori dan konsep yang mendasari pengembangan sintak pembelajaran adalah;

Tabel 6. Referensi Pendukung Sintak Model Pembelajaran EXO OLO TASK

\begin{tabular}{ll}
\hline $\begin{array}{c}\text { Sintak Model Pembelajaran } \\
\text { EXO OLO TASK }\end{array}$ & Referensi Pendukung \\
\hline 1. &
\end{tabular}

\begin{tabular}{|c|c|c|}
\hline \multirow{3}{*}{\multicolumn{2}{|c|}{$\begin{array}{l}\text { Penguatan Konsep } \\
\text { (Strengthening Concept) }\end{array}$}} & $\begin{array}{l}\text { 1. "Generative Learning” diawali dengan "Process } \\
\text { Learning" ((Slavin;1994, Jonassen;1985, Wittrock;1974, } \\
\text { Kemp et al;1994). }\end{array}$ \\
\hline & & $\begin{array}{l}\text { 2. Ormrod (2008): aktivasi pengetahuan awal (prior } \\
\text { knowledge activation) adalah proses mengingatkan peserta } \\
\text { didik tentang hal-hal yang telah mereka ketahui yang } \\
\text { berkaitan dengan topik baru merupakan upaya untuk } \\
\text { mencapai pembelajaran bermakna (meaningfull learning). }\end{array}$ \\
\hline & & $\begin{array}{l}\text { 3. Perhatian siswa akan meningkat melalui rancangan } \\
\text { aktivitas khusus di kelas (Kanfer \& Kanfer, 1991;Schunk, } \\
\text { 2012). }\end{array}$ \\
\hline
\end{tabular}

2. Examination Task/EXO Task

3. Olympiad Task/OLO Task

Oriented

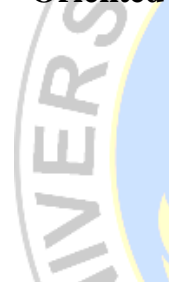

1. Pengetahuan dibangun oleh peserta didik melalui kontak dengan lingkungan, tantangan dan bahan yang dipelajari (Suparno, 2013).

2. Otak bekerja lebih baik jika membahas informasi dengan orang lain (Ruhl, Hughes dan Scholes (1987); Silbermen (2006).

Oriented 1. Soal yang sulit cara mendorong siswa untuk belajar asalkan masih dalam ZPD (Vygotsky, 1978;Sato, 2012).

2. Tindakan sosial yang dialami dimana siswa saling berbicara dan berkomunikasi membantu mereka dalam menyelesaikan suatu masalah (Gerlach, J. M., 1994 \& Laal, Laal., 2012).

3. Tugas yang menantang adalah salah satu ciri pembelajaran yang efektif (Silbermen, 2006).

4. Dialog kelas sangat bermanfaat bagi pendidik, karena dengan memonitor komentar ataupun pertanyaan mereka secara cermat, pendidik dapat mengidentifikasi dan menyelesaikan yang bisa menghambat kemampuan mereka untuk memperoleh pengetahuan dan keterampilan yang lebih luas lagi. (Presseisen, dkk, 1994, (dalam Ormrod, 2008)

4. Reflection

1. Peninjauan, penilaian diri akan membantu menciptakan belajar sebagai kegiatan yang tidak terlupakan (Silbermen, 2006). 
Sedangkan uraian pelaksanaan pembelajaran berupa kegiatan guru dan kegiatan siswa dijelaskan pada tabel berikut ini;

Tabel 7. Uraian Sintak Pembelajaran dan Gambaran Kegiatan Siswa dan Guru dalam Model Pembelajaran EXO OLO TASK

\begin{tabular}{|c|c|c|}
\hline No & $\begin{array}{c}\text { Sintak/Tahap-tahap } \\
\text { Pembelajaran }\end{array}$ & Uraian Kegiatan Pembelajaran \\
\hline 1 & $\begin{array}{c}\text { Penguatan Konsep } \\
\text { dengan teknik Kata } \\
\text { Kunci } \\
\text { (Concept } \\
\text { Strengthening) }\end{array}$ & $\begin{array}{l}\text { Menelusuri pengetahuan awal siswa, memberikan penguatan } \\
\text { dan memastikan bahwa siswa telah memiliki pengetahuan awal } \\
\text { yang memadai dengan menggunakan Teknik Kata Kunci. } \\
\text { KEGIATAN GURU; } \\
\text { 1. Menugaskan siswa untuk mencari dan membaca materi. } \\
\text { 2. Mempraktikan Teknik Kata Kunci untuk mengetahui } \\
\text { pengetahuan awal siswa. } \\
\text { 3. Mengelola aktivitas belajar berupa aktivitas individu } \\
\text { 4. Memberikan penguatan. } \\
\text { KEGIATAN SISWA; } \\
\text { 1. Mencari dan membaca materi. } \\
\text { 2. Mencari arti kata kunci dan hubungan antar kata kunci. } \\
\text { 3. Menyampaikan temuan atau hasil pencarian kata kunci } \\
\text { 4. Menanyakan materi yang belum dipahami. } \\
\text { 5. Menyimak penguatan yang disampaikan guru. }\end{array}$ \\
\hline 2 & $\begin{array}{c}\text { EXO TASK } \\
\text { (Soal Kategori LOT } \\
\text { dan MOTS) }\end{array}$ & $\begin{array}{l}\text { Mengembangkan landasan kemampuan berfikir tingkat tinggi } \\
\text { siswa berupa LOTS dan MOTS. } \\
\text { KEGIATAN GURU; } \\
\text { 1. Mengelola kegiatan belajar dalam bentuk aktivitas berpasangan. } \\
\text { 2. Memberikan paket soal EXO (C1-C3). } \\
\text { 3. Mengobservasi pembelajaran. } \\
\text { 4. Memberikan bantuan (scaffolding) sesuai kebutuhan. } \\
\text { 5. Menyajikan penjelasan dan penguatan. } \\
\text { KEGIATAN SISWA; } \\
\text { 1. Mengerjakan soal dengan pasangan masing-masing. } \\
\text { 2. Mendiskusikan dan Menyajikan hasil temuan. } \\
\text { 3. Menanyakan soal yang belum dipahami (kepada pasangan atau } \\
\text { pasangan lain). } \\
\text { 4. Berdialog }\end{array}$ \\
\hline 3 & $\begin{array}{c}\text { OLO TASK } \\
\text { (Soal Kategori HOTS) } \\
\text { Olympiad Oriented } \\
\text { Task }\end{array}$ & $\begin{array}{l}\text { Mengembangkan Keterampilan Berfikir Tingkat Tinggi/HOTS } \\
\text { Siswa. } \\
\text { KEGIATAN GURU; } \\
\text { 1. Menempatkan siswa dalam kelompok (4 orang/kelompok). } \\
\text { 2. Memberikan soal OLO (C4-C6) } \\
\text { 3. Mengobservasi pembelajaran } \\
\text { 4. Memberikan bantuan (scaffolding) sesuai kebutuhan. } \\
\text { 5. Menjadikan penjelasan dan penguatan. } \\
\text { KEGIATAN SISWA; } \\
\text { 1. Mengerjakan soal dalam kelompok. } \\
\text { 2. Mendiskusikan dan menyajikan temuan }\end{array}$ \\
\hline
\end{tabular}


3. Menanyakan soal yang belum dipahami (dalam kelompok atau antar kelompok).

4. Berdialog dan berkolaborasi

Peninjauan perkembangan diri dan refleksi pembelajaran.

KEGIATAN GURU;

4

Refleksi

Reflection

1. Memfasilitasi siswa untuk melakukan refleksi proses pembelajaran dengan format 3-2-1 (TWC).

2. Memberikan penguatan.

KEGIATAN SISWA;

1. Menyampaikan hasil peninjauan perkembangan diri dan refleksi pembelajaran.

\section{Prinsip Reaksi}

Sesuai dengan prinsip pembelajaran Kurikulum 2013, fungsi guru dalam model ini adalah sebagai fasilitator pembelajaran. Guru memainkan peran sebagai pendorong, pemberi stimulus, penguat serta pemicu aktivitas belajar melalui penyajian soal EXO dan OLO. Proses pembelajaran fokus pada siswa (student centre) yang bertumpu pada aktivitas dan proses belajar serta mengacu pada pembelajaran $4 \mathrm{~K}$ yaitu, 1) creative, 2) critical thinking, 3) communication, 4) collaboration.

\section{Sistem Sosial}

Ciri khas sistem sosial dalam model pembelajaran ini adalah dialog, interaksi dan kolaborasi dengan mengimplementasikan konsep Zone of Proximal Development/ZPD. Aktivitas belajar dikelola dalam bentuk aktivitas individu, berpasangan dan berkelompok. Guru memberikan bantuan yang diperlukan lalu mengurangi bantuan itu saat siswa mulai menemukan solusi. Pembelajaran didasari oleh konsep ZPD dimana potensi siswa akan bisa meningkat jika mereka saling berinteraksi dan berdialog serta berkolaborasi.

\section{4. $\quad$ Sistem Pendukung}

Sistem pendukung model pembelajaran ini adalah perangkat pembelajaran seperti silabus, RPP, LKPD, Lembar Observasi Aktivitas Belajar, Lembar Refleksi Pembelajaran. Selain itu adalah ketersediaan observer pembelajaran, teknisi untuk mendokumentasikan pembelajaran serta dukungan pimpinan sekolah dan teman sejawat.

\section{Dampak Instruksional}


Dampak instruksional dari model pembelajaran ini adalah berkembangnya keterampilan berpikir tingkat tinggi siswa dan meningkatnya kualitas aktivitas belajar siswa.

\section{Dampak Pengiring}

Dampak pengiring dari model pembelajaran ini adalah terciptanya tanggung jawab, saling peduli dan saling menghargai, daya juang dan kreativitas.

\section{E. Keunggulan Model Pembelajaran EXO OLO TASK.}

Sebagai pengembang model pembelajaran ini, peneliti menyampaikan keunggulan Model Pembelajaran EXO OLO TASK ini adalah sebagai berikut:

1. Dikembangkan atas dasar teori belajar konstruktivistik dan pembelajaran kolaboratif yang relevan dengan kerangka pembelajaran Abad 21 dan IP2CSS serta sesuai dengan pembelajaran Kurikulum 2013.

2. Memiliki sintak atau langkah-langkah pembelajaran yang sederhana dan mudah dipahami pendidik dan peserta didik.

3. Mengembangkan dialog, interaksi dan kolaborasi dalam bentuk saling peduli.

4. Melatih peserta didik untuk mengasah keterampilan berpikir tingkat tinggi (Higher Order Thinking Skills/HOTS) dan memiliki strategi kognitif.

5. Mengembangkan karakter positif di kalangan peserta didik seperti jujur, tanggung jawab, percaya diri dan disiplin serta saling peduli dan saling mempercayai.

Jika dibandingkan dengan praktik pembelajaran di berbagai dunia maka akan tampak bahwa Model Pembelajaran EXO OLO TASK relevan dengan pembelajaran di berbagai negara maju namun dalam kemasan yang lebih sederhana dan praktis. Seperti dinyatakan dalam Buku 'The Teaching Gap; Best Ideas from the World's Teacher for Improving Education in the Classroom" karya Stigler \& Hiebert (2009). Untuk memudahkan dalam membandingkannya, penulis menyebut praktik pembelajaran di negara-negara yang dibahas dengan istilah model pembelajaran karena di dalam buku ini 
juga dinyatakan dengan istilah "sequence of learning activity" atau urutan aktivitas pembelajaran (Stigler \& Hiebert, 2009).

Tabel 8. Perbandingan Langkah-langkah Pembelajaran antara Model Pembelajaran EXO-OLO Task dengan Praktik Pembelajaran di Jerman, Jepang dan USA

\begin{tabular}{|c|c|c|c|c|}
\hline $\begin{array}{c}\text { Urutan } \\
\text { Aktivitas } \\
\text { Pembelajara } \\
\mathrm{n}\end{array}$ & $\begin{array}{c}\text { Model EXO-OLO } \\
\text { Task }\end{array}$ & Jerman & Japan & USA \\
\hline 0 & Opening & Opening & Opening & Opening \\
\hline 1 & $\begin{array}{l}\text { Strengthening } \\
\text { Concept by } \\
\text { Keyword Technic }\end{array}$ & $\begin{array}{l}\text { Reviewing } \\
\text { previous } \\
\text { material }\end{array}$ & $\begin{array}{l}\text { Reviewing } \\
\text { the previous } \\
\text { lesson }\end{array}$ & $\begin{array}{l}\text { Reviewing } \\
\text { the previous } \\
\text { material }\end{array}$ \\
\hline 2 & $\begin{array}{l}\text { EXO Task and } \\
\text { Discussion } \\
\text { (Presenting the } \\
\text { Examination- } \\
\text { Oriented Task } \\
\text { and solve the } \\
\text { task is } \\
\text { discussion in } \\
\text { Individually or } \\
\text { Paired learning } \\
\text { acitivity) }\end{array}$ & $\begin{array}{l}\text { Presenting } \\
\text { the topic } \\
\text { and the } \\
\text { problem for } \\
\text { the day }\end{array}$ & $\begin{array}{l}\text { Presenting } \\
\text { the problem } \\
\text { for the day }\end{array}$ & $\begin{array}{l}\text { Demonstrati } \\
\text { ng how to } \\
\text { solve the } \\
\text { problem for } \\
\text { the day }\end{array}$ \\
\hline 3 & $\begin{array}{l}\text { OLO Task and In- } \\
\text { depth Discussion } \\
\text { (Presenting the } \\
\text { Olympiad- } \\
\text { Oriented Task } \\
\text { and Solve the } \\
\text { task in Groups) }\end{array}$ & $\begin{array}{l}\text { Developing } \\
\text { the } \\
\text { procedure to } \\
\text { solve the } \\
\text { problem }\end{array}$ & $\begin{array}{l}\text { Students } \\
\text { working } \\
\text { individually } \\
\text { or in groups }\end{array}$ & Practicing \\
\hline 4 & $\begin{array}{l}\text { Reflection } \\
\text { (use the Three } \\
\text { Ways Conference } \\
\text { Technic with } \\
\text { formula 3-2-1) }\end{array}$ & Practicing & $\begin{array}{l}\text { Discussion } \\
\text { solution } \\
\text { methods }\end{array}$ & $\begin{array}{l}\text { Correcting } \\
\text { seatwork and } \\
\text { assigning } \\
\text { homework }\end{array}$ \\
\hline 5 & Closure & Closure & Closure & Closure \\
\hline
\end{tabular}

Sumber : Stigler \& Hiebert (1999)

Dari keempat urutan aktivitas pembelajaran yang telah dinyatakan di dalam tabel di atas terlihat bahwa keempat pola yang ada sama-sama memiliki 
langkah "reviewing the previous material/lesson". Namun, perbedaan sedikit terlihat pada langkah berikutnya yaitu:

1. Di kelas Jerman dan USA, setelah memberikan soal atau tugas, guru memberikan contoh pengerjaan soal. Berbeda dengan kelas Jepang, dimana setelah diberikan soal atau tugas, siswa langsung bekerja secara individu atau berkelompok.

2. Di Kelas Jerman, guru benar-benar memandu siswa untuk mengerjakan tugas/soal. Sedangkan di kelas Jepang, guru akan memberikan ringkasan atau penguatan setelah siswa mempresentasikan hasil kerjanya. Sedikit berbeda dengan keduanya, kelas di USA, guru di awal mendemonstrasikan cara mengerjakan suatu soal lalu setelah itu memeriksanya.

3. Di Jerman, guru memberikan tugas untuk dikerjakan di rumah jika tugas hari ini tidak bisa diselesaikan. Di Jepang guru tidak memberikan tugas untuk dikerjakan di rumah. Sedangkan di USA, guru memberikan tugas dan memeriksanya dengan ketat.

4. Dalam pembelajaran dengan menggunakan Model Pembelajaran EXOOLO Task, pada kegiatan awal, guru memeriksa kesiapan siswa atau mencari tahu kemampuan awal siswa tentang materi yang akan dipelajari dengan menggunakan teknik “The Power of Keywords". Hal ini berguna untuk memastikan bahwa siswa benar-benar telah membaca materi yang akan dipelajari di rumah. Dalam praktik model ini, guru tidak memberikan soal untuk dikerjakan di rumah, namun guru memberikan tugas kepada siswa untuk membaca materi yang akan dipelajari pada pertemuan berikutnya. Dalam model pembelajaran EXO-OLO Task, soal yang diberikan kepada siswa disajikan secara berjenjang dimulai dari soal sesuai tuntutan kurikulum. Setelah tuntas, baru diberikan soal yang menuntut kemampuan berfikir tingkat tinggi. Hal ini sedikit berbeda dengan praktik di Jepang dimana guru bisa saja memberikan soal-soal sulit di awal pembelajaran. 
Ditinjau dari posisi guru dalam model pembelajaran ini memiliki sedikit perbedaan dengan praktik model atau metode pembelajaran oleh guru yang sering ditemui di kelas. Pada praktik model/metode pembelajaran oleh guru di kelas selama ini, model ditempatkan sebagai bagian terpisah dari diri guru itu sendiri. Guru menggunakan suatu model pembelajaran untuk mengajarkan suatu materi lalu siswa menjadi pelaksana model tersebut. Sedangkan pada Model Pembelajaran EXO OLO TASK, terdapat pengaruh timbal balik antara guru, model dan siswa. Guru adalah bagian dari model pembelajaran itu sendiri. Langkah-langkah model pembelajaran tidak hanya mengenai diri siswa tapi juga guru. Semua terlibat secara aktif dan produktif. Kondisi seperti ini seharusnya terjadi pada setiap pembelajaran di Indonesia karena pembelajaran seperti ini adalah pembelajaran yang efektif dan produktif. Dalam pembelajaran dengan menggunakan Model Pembelajaran EXO OLO TASK, guru melatih siswa untuk menjadi pembelajar yang handal (more powerful learners) dimana siswa diarahkan serta mengelola aktivitas belajarnya sendiri dalam memperoleh informasi, gagasan, keterampilan, nilai, cara berfikir dan mengekspresikan diri. Aktivitas ini dapat dilihat pada setiap langkah-langkah pembelajaran. Merujuk kepada pendapat Sato (2012), ini merupakan salah satu bentuk "silent revolution" atau revolusi damai di dalam kelas yang berhasil dicapai dengan penerapan Model Pembelajaran EXO OLO TASK.

Pada praktik pembelajaran dengan model/metode lain yang sering dilakukan guru, seorang guru lebih fokus kepada penerapan langkah-langkah pembelajaran untuk siswa sedangkan di sisi lain, guru tersebut lupa dengan dirinya. Bisa dikatakan, hanya model atau metode pembelajaran yang berubah namun sedikit sekali perubahan pada diri guru. Guru bisa saja menerapkan model atau model yang berbeda di dalam pembelajaran setiap minggunya namun belum bisa dijamin guru mempersiapkan materi dengan semestinya juga pada setiap minggunya. Disinilah letak keunggulan Model Pembelajaran EXO OLO TASK yang mampu berpengaruh timbal balik terhadap pendidik dan peserta didik. Aktivitas peserta didik ditata, dikelola dan diarahkan sebagai 
suatu cara bagi mereka dalam mempelajari suatu materi, atau mengajari bagaimana cara mempelajari sesuatu bukan hanya mengajarkan suatu materi pembelajaran. Oleh karena itu, pelaksanaan model pembelajara EXO OLO TASK bisa memutuskan 'fault line/garis kecacatan” dalam pembelajaran.

Dalam implementasikan model ini, guru terlibat secara utuh dan justru di tangan gurulah letak keberhasilan model pembelaran EXO OLO Task. Guru harus menyiapkan pembelajaran berupa RPP. Bahan Ajar, perangkat penilaian serta LKPD siswa setiap minggu dengan dua tingkatan soal yaitu EXO TASK dan OLO Task. Selama proses pembelajaran berlangsung, guru lebih banyak berperan sebagai observator pembelajaran dan diakhiri dengan refleksi. Dari uraian di atas terlihat bahwa terjadi pergeseran aktivitas belajar dimana guru adalah sebagai bagian tidak terpisahkan dari pembelajaran.

\section{DAFTAR RUJUKAN}

Laal, M \& Laal, M. 2012. Collaborative Learning: What is it?. Journal of ProcediaSocial and Behavioral Science: 31, 491-495

Laal, Marjan, Geranpaye, Loabad, Daemi Mahrah. 2013. Individual Accountability in Collaborative Learning Third World Conference on Learning Teaching and Educational Leadership (WCLTA) 2012. Procedia-Social Behavioral Sciences 9 (3): 286-289

Ormrod. J.E. 2008. Psikologi Pendidikan; alih bahasa Triwibowo. J.S. Jakarta: Erlangga

Schunk, Dale H. 2012. Learning Theories: An Educational Perspective, Fifth Edition. New Jersey:Pearson Prentice Hall

Sato, Manabu. 2012. Mereformasi Sekolah. Jakarta. PELITA/JICA

Silbermen L. Melvin. 2006. Active Learning (101 Cara Belajar Siswa Aktif). Penerbit Nusa Media \& Nuansa. Bandung

2011. Active Learning (101 Cara Belajar Siswa Aktif). Penerbit Nusa Media \& Nuansa. Bandung 
Stigler W, James \& Hiebert, James. 2009. The Teaching Gap;Best Ideas from the World's Teachers for Improving Education in The Classroom. Free Press. New York

Vygotsy, L, S. 1978. Mind in Society. Cambridge;Harvard University Press

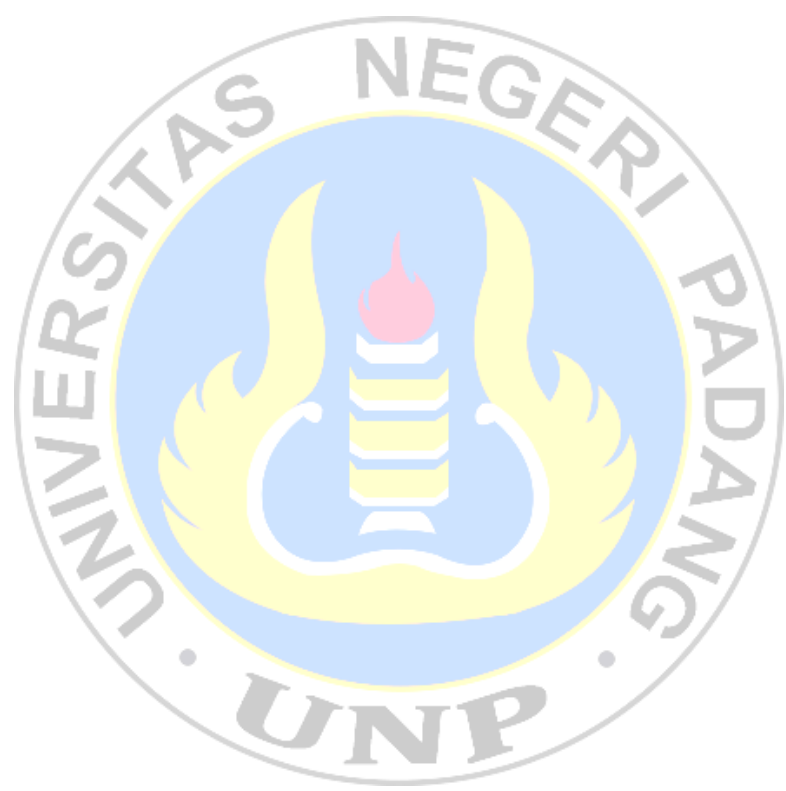




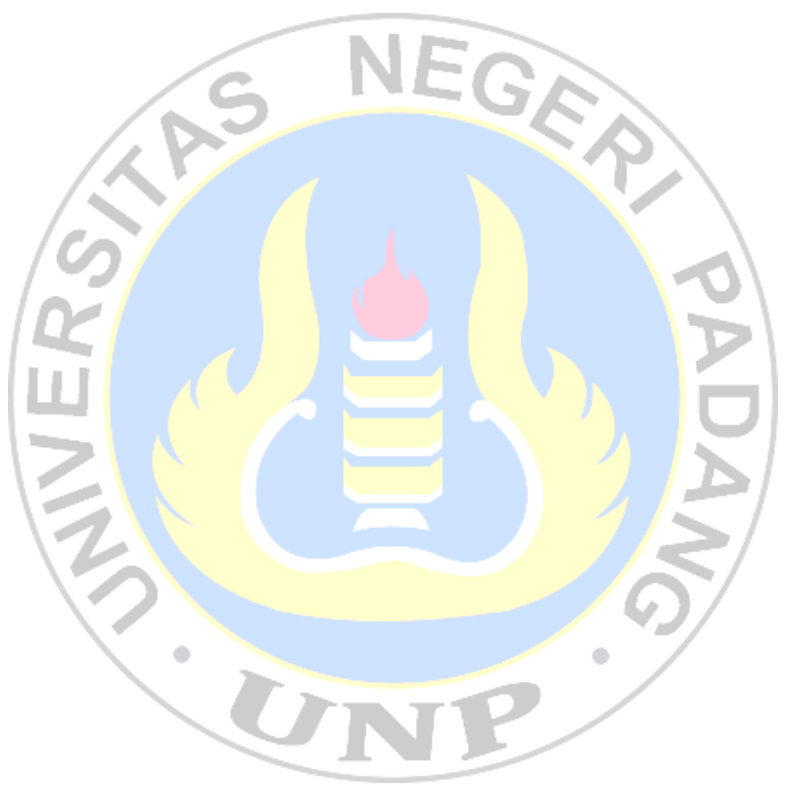

